Transportation Research Forum

The Impact of Information Technology on Motor Carrier Productivity Author(s): B. Starr McMullen

Source: Journal of the Transportation Research Forum, Vol. 43, No. 2 (Fall 2004), pp. 7-23

Published by: Transportation Research Forum

Stable URL: http://www.trforum.org/journal

The Transportation Research Forum, founded in 1958, is an independent, nonprofit organization of transportation professionals who conduct, use, and benefit from research. Its purpose is to provide an impartial meeting ground for carriers, shippers, government officials, consultants, university researchers, suppliers, and others seeking exchange of information and ideas related to both passenger and freight transportation. More information on the Transportation Research Forum can be found on the Web at www.trforum.org. 


\section{The Impact of Information Technology on Motor Carrier Productivity}

This study examines the relationship between motor carrier productivity, marketing strategy, and use of information technology for a sample of U.S. general freight commodity carriers. We use a unique data set containing information on firm marketing strategy and information technology use collected in a survey of Class I and II motor carrier firms (U.S. Department of Transportation, 1999).

The measure of productivity used here is the non-parametric Malmquist Index as explained in Grosskopf (1993) and previously applied to general freight motor carriers by McMullen and Okuyama (2000). The Malmquist Index is decomposed into two components: economic efficiency change (EC) and technical efficiency change (TC).

A tobit model regression model is used to examine the relationship between firm productivity, marketing strategy, and use of information technology. Information technologies included in the tobit analysis are electronic data interchange (EDI) and satellite communications (SATCOM). We also include firm size, use of owner-operators, and percent unionization as explanatory variables in the tobit regression.

Results indicate that use of EDI has a positive and significant impact on economic efficiency (EC). Firms that try to market their product by providing service at the "lowest freight rate" are found to exhibit greater technical efficiency (TC), suggesting that productivity and cost measures that ignore marketing strategy may be biased. Finally, economic efficiency (EC) is found to be significantly greater for firms that are more heavily unionized.

\section{by B. Starr McMullen}

\section{INTRODUCTION}

The U.S. trucking industry has faced competitive market conditions since the Motor Carrier Act of 1980 (MCA) eliminated most economic regulations and left the industry to the vagaries of the marketplace. It is generally acknowledged that in a competitive industry inefficient firms will not survive in the long run. Thus, without the protection of governmental regulation it becomes important for firms to use existing resources efficiently and adopt technologies that will increase efficiency and firm productivity. Indeed, increasing trucking productivity is an important goal for the U.S. motor carrier industry (Barnes, 1999).
There is evidence that motor carrier firms in the post-regulation period have become more efficient and productive. In a study of general freight commodity carriers, McMullen and Lee (1999), use a stochastic cost frontier to measure efficiency. As expected by economic theory, they find that firms surviving in the deregulated industry were those found to be the most cost efficient. Using a non-parametric Malmquist productivity approach, McMullen and Okuyama (2000) find that immediately following deregulation, economic efficiency improved as general freight firms were able to rationalize their network structures without the constraints on pricing and operations experienced under industry regulation. 
One shortcoming of productivity and efficiency measures is that they do not account for service quality dimensions that are known to influence motor carrier costs. For instance, McMullen and Okuyama (2000) argue that the deregulated efficiency and productivity gains they find may be understated due to an inability to account for changes in firm marketing strategy following deregulation. Firms that try to provide service at the lowest possible freight rate need to cut costs and thus may appear more resource-efficient than firms that strive to provide various kinds of high service quality. For instance, on-time performance (OTP) is a marketing strategy that tends to be more resource intensive than a low freight rate (LFR) strategy. If firms that focus on LFR strategies consistently show higher measured productivity, this does not necessarily mean that all trucking firms should switch to an LFR strategy if there is shipper demand for OTP or other services that result in lower measured productivity. Thus, it is important to determine whether marketing strategy has a significant impact on measured productivity before making interfirm comparisons based on existing productivity measures. Therefore, the objective of this paper is to measure the relationship between motor carrier productivity, marketing strategy, and the use of information technology.

Basic economic theory suggests that productivity growth will result as firms adopt new and more efficient technologies. The adoption of information and computer technologies in the 1990s was heralded as the harbinger of great advances in overall economic productivity and growth. However, much of the general economic literature exploring the relationship between information technologies and productivity has yielded mixed results (Brynjolfson and Hitt, 2000; Chakrabortny and Kazarosian, 2001). Part of the reason may be that information technologies allow firms to organize production in ways that do not increase productivity but rather reduce the costs of transactions.

Hubbard (2001) argues that trucking firms use owner-operators rather than company drivers because owner-operators need less monitoring to avoid shirking activities or inefficient driving practices because they own the vehicle and have a vested interest in using it in as efficient manner as possible. He goes on to argue that adoption of on-board computers causes firms to change the way in which they organize production. Specifically, by providing carriers with technologies that allow them to monitor company drivers, they can increase the efficiency of company drivers and use a smaller percentage of owner-operators. Note that this may not actually increase efficiency or productivity, but could simply represent a change in the way firms do business. Thus, the expected economic effect is that adoption of new technologies will result in productivity gains - although there are reasons to question whether such gains are realized.

This study focuses on general freight motor carriers, the part of the trucking industry examined by both McMullen and Okuyama (2000) and McMullen and Lee (1999) in studies of trucking productivity and efficiency. We use a unique data set, the Motor Carrier Safety, Operations, and Technology (MCSOT) survey conducted by the American Trucking Association (ATA). The MCSOT survey collected data on information technology use in 1996 and 1998 as well as the ranking of marketing strategies employed by each motor carrier firm in the sample. The survey instrument was sent to Class I and II for-hire motor carrier firms engaged in interstate commerce that responded to the U.S. Bureau of Transportation Statistics annual survey of financial and operating statistics. Thus, it was possible to match a firm's financial and operating statistics with data indicating their marketing strategy and use of information technology. (USDOT, 1999; Chakrabortny and Kazarosian, 2001).

The measure of productivity used here is the non-parametric Malmquist Index as explained by Grosskopf (1993 ) and used in the study by McMullen and Okuyama (2000). The Malmquist Index can be decomposed into two components: economic efficiency change (the part of productivity gain which results from a firm using its given inputs to get more 
output) and technical efficiency change (increases in productivity due to technological change.)

Once the Malmquist Productivity Index number and its component economic efficiency and technological efficiency indices are calculated, a tobit regression model is estimated to determine the extent to which information technology and marketing strategy affect productivity gains.

The following section provides a brief introduction to the information technologies considered in this study.

\section{INFORMATION TECHNOLOGIES}

Information technologies are expected to impact motor carrier operations through a number of channels. First, they can help carriers increase vehicle utilization through increased monitoring and reducing unnecessary out-of-route miles by drivers. Second, fuel costs may be reduced as technologies are used to improve routing. Finally, administrative costs are expected to fall as new technologies are adopted that enable paperless transactions.

Advanced information technologies fall into two groups: on-board technologies and backroom technologies. The three on-board technologies considered here were on-board computers (OBC), satellite communications (SATCOM), and automatic vehicle location (AVL) - all technologies physically carried on the truck. On-board computers (OBC) basically process data received from sensors and other devices located on trucks. They keep records of readings and provide the fleet operator with performance information necessary to monitor drivers.

Hubbard (2001) argues that on-board computers give fleet managers a way to measure driver performance, thus reducing monitoring costs. Trucking firms have a choice between hiring drivers to operate their trucks or hiring owner-operators. Because owner-operators own and operate their own trucks and usually pay for fuel, they have a vested interest in maintaining their truck and pro-viding good fuel mileage. Without an effective monitoring system for company drivers (who do not have a vested interest in their trucks,) many firms choose to use owneroperators because of the lower monitoring costs. Hubbard (2001) finds that over time, as firms adopt on-board computers, they use more company drivers relative to owneroperators. If this is how on-board computers are used, then one would not necessarily expect a change in overall productivity, but a change in the way firms choose to organize production as OBCs are adopted.

SATCOM and AVL are two other onboard technologies considered here. These technologies make it possible for firms to identify the location of trucks at any point in time. In addition to vehicle tracking, SATCOM technologies provide communication between the vehicle and the dispatcher which allows for real time coordination of fleet routing and dispatching activities. Thus, SATCOM can be thought of as an "active" technology where there is immediate feedback between the truck, dispatchers, and shippers whereas AVL is a "passive" technology which does not allow for ease of communication between the firm and the drivers. SATCOM is often used in combination with AVL and OBC technologies (USDOT, 1999, p.18).

Electronic data interchange (EDI) is a backroom strategy which makes information available to both the shipper and the carrier in a more accurate and timely manner. The adoption of EDI is strongly driven by consumer (shipper) demand for conducting business electronically. This technology allows for computer communications which enable transmission of information more easily between companies. For instance, EDI allows information on the status of shipments to be transmitted between shipper and carrier quickly. EDI is also used to allow billing, invoicing and other financial transactions between firms to take place electronically. EDI use increased in the 1990s as documented by Crum, Johnson, and Allen (1998) who find that the greatest perceived benefit of EDI is in providing better consumer service. Their 1996 survey results also show that carriers perceived increased office/clerical efficiency 
as a benefit of EDI use. Thus, there is reason to believe that the adoption of EDI may contribute to overall motor carrier productivity.

The other backroom technologies considered were computer aided dispatching (CAD) and computer aided routing (CAR), both of which are expected to be positively related to productivity improvements in trucking through better utilization of equipment. The use of these technologies is often integrated with the on-board computer technologies, especially SATCOM and AVL systems, which identify locations for dispatchers.

\section{MARKETING STRATEGIES}

Following the MCA of 1980, firms in the increasingly competitive industry began to adopt different sorts of marketing strategies. Corsi et al (1991) find that firms pursued marketing strategies that either provided service at the lowest freight rate (LFR), or provided high service quality, usually distinguished by reliable and on-time performance (OTP).

Shippers of high-value commodities might be willing to pay more for on-time service than shippers of lower-value commodities who were more interested in the transportation rates. Although both price and quality are important to shippers, some give more weight to one or the other and, accordingly, some motor carrier firms concentrate more on service quality such as OTP while others focus on providing service at the least possible rates ( LFR) .

The reason to be concerned about marketing strategy is that it usually costs more to provide output if an OTP or other strategy that focuses on high service quality is pursued, than if an LFR strategy is followed. Because the productivity measures use only physical units of input and output, firms that pursue OTP strategies may appear to be less efficient than firms which are concentrating on providing LFR service. Thus, it is important to consider the marketing strategy pursued by firms when trying to compare productivity across firms.

Fortunately, in addition to the Motor Carrier Technology (MCSOT) data on carrier technologies, it also asked that firms rank five different marketing strategies: lowest freight rates (LFR), on-time performance (OTP), short turn around on customer requests (STRCR), safety performance (SAFETY), and specialized/dedicated equipment (SPEC). Respondents rated each strategy on a scale of one to five, one being the most important. Table 1 shows the ranking of marketing strategy for the MCSOT survey's sample of all general freight carriers as well as the subset of 124 carriers used for this study.

The following section introduces the Malmquist methodology used to measure productivity in this study. The data and the empirical Malmquist productivity results are then presented along with a tobit regression which is used to identify significant factors influencing productivity. These factors include the technological variables discussed above in addition to marketing strategies and a couple of other variables expected to influence motor carrier productivity.

\section{MALMQUIST PRODUCTIVITY INDEX}

The original derivation of the Malmquist Index, which uses the Shephard (1953) concept of distance functions, can be found in Caves, Christensen, and Diewert (1982). The discussion here closely follows the presentation found in Fare, Grosskopf, and Lee (1995). Application of these techniques include Forsund (1993); Fare, Grosskopf, Lindgren, and Roos (1992); and Fare, Grosskopf, Norris, and Zhang (1994).

The basic intuition is to define an efficient production frontier, constructed using observed data points. This frontier then represents efficient production given the existing technology. Efficiency in any year is measured as each firm's distance from the production frontier. 


\section{Table 1: Number of MCSOT Survey General Freight Firms \\ Ranking Marketing Strategies on a 1-5 Scale: 1996 \\ (1=most important, $5=$ =least important)}

\begin{tabular}{cccccc}
\hline \multicolumn{5}{c}{} & \multicolumn{4}{c}{ General Freight Sample (n= 347) } \\
Rank & LFR & OTP & STACR & SPEC & SPERF \\
\hline 1 & 30 & 266 & 16 & 33 & 17 \\
2 & 70 & 54 & 87 & 61 & 53 \\
3 & 57 & 11 & 111 & 84 & 54 \\
4 & 67 & 4 & 59 & 89 & 84 \\
5 & 77 & 8 & 43 & 64 & 99 \\
6 & 43 & 3 & 21 & 12 & 30 \\
& & & & & \\
Rank & LFR & Sub-Sample with Complete Data (n=124) & SPERF \\
\hline 1 & 11 & OTP & STACR & SPEC \\
2 & 27 & 19 & 69 & 11 & 18 \\
3 & 15 & 7 & 44 & 22 & 14 \\
4 & 30 & 1 & 21 & 33 & 26 \\
5 & 27 & 2 & 12 & 24 & 40 \\
6 & 13 & 8 & 6 & 15 \\
\hline
\end{tabular}

Source: Unpublished data collected in the MCSOT (USDOT,1999) survey and provided to the author.

The actual calculation of the frontier is achieved using linear programming, usually data envelope analysis (DEA) techniques introduced by Charnes, Cooper, and Rhodes (1978). For a theoretical discussion of DEA, see Lovell (1993) and Grosskopf (1993). DEA techniques produce Farrell (1957) efficiency measures which are identical to the distance functions required for the Malmquist Index (Forsund, 1993).

The model used here assumes constant returns to scale, an assumption consistent with the results of Bruning and Olson (1982) who used efficiency indexes to test for economies of scale in U.S. trucking. Many other researchers have found evidence of constant returns, both before and after the Motor Carrier Act of 1980 (McMullen and Stanley, 1987; Grimm, Corsi, and Jarrell, 1989; McMullen and Tanaka, 1995; Adrangi, Chow and Raffiee, 1995). To derive the Malmquist Index, we assume a production technology, $\mathrm{S}$ $=\left\{\left(\mathrm{x}^{\mathrm{t}}, \mathrm{y}^{\mathrm{t}}\right): \mathrm{x}^{\mathrm{t}}\right.$ can produce $\left.\mathrm{y}^{\mathrm{t}}\right\}$, which describes all possible sets of input $(\mathrm{x})$-output $(\mathrm{y})$ vectors for each time period, $\mathrm{t}=1, \ldots \mathrm{T}$.
The output based distance function at time t, $\boldsymbol{D}_{\boldsymbol{0}}{ }^{t}\left(\boldsymbol{x}^{t}, \boldsymbol{y}^{t}\right)$ is then defined as:

(1) $D_{o}^{t}\left(x^{t}, y^{t}\right)=\inf \left[\theta:\left(x^{t}, y^{t} / \theta\right) \in S^{t}\right]$

This function is homogeneous of degree one in outputs and completely describes the technology in that $\left(x^{t}, y^{t}\right)$ belongs to $S^{t}$ only if $D_{0}^{t}\left(x^{t}, y^{t}\right)$ is less than or equal to one.

Caves, Christensen, and Diewert (1982) introduced the Malmquist Productivity Index, which involves the use of mixed time distance functions using information from both periods, $t$ and $t+1$ :

$$
D_{o}^{t+1}\left(x^{t}, y^{t}\right)=\inf \left[\theta:\left(x^{t}, y^{t} / \theta\right) \in S^{t+1}\right]
$$

and

$$
D_{o}^{t}\left(x^{t+1}, y^{t+1}\right)=\inf \left[\theta:\left(x^{t+1}, y^{t+1} / \theta\right) \in S^{t}\right]
$$

The Malmquist Productivity Index can be written as the geometric mean of two mixed period distance functions (Fare, Grosskopf, and Lee, 1995): 


$$
M_{o}\left(x^{t 1}, y^{t 1}, x^{t}, y^{t}\right)=\left[\frac{D_{o}^{t}\left(x^{t 1}, y^{t 1}\right)}{D_{o}^{t}\left(x^{t}, y^{t}\right)} \frac{D_{o}^{t}\left(x^{t 1}, y^{t 1}\right)}{D_{o}^{t 1}\left(x^{t}, y^{t}\right)}\right]^{1 / 2}
$$

Following Fare, Grosskopf, Lindgren, and Roos (1989), equation (4) can be rewritten as:

$$
M_{o}\left(x^{t 1}, y^{t 1}, x^{t}, y^{t}\right)=\frac{D_{o}^{t 1}\left(x^{t 1}, y^{t 1}\right)}{D_{o}^{t}\left(x^{t}, y^{t}\right)}\left[\frac{D_{o}^{t}\left(x^{t 1}, y^{t 1}\right)}{D_{o}^{t 1}\left(x^{t 1}, y^{t 1}\right)} \frac{D_{o}^{t}\left(x^{t}, y^{t}\right)}{D_{o}^{t 1}\left(x^{t}, y^{t}\right)}\right]^{1 / 2}
$$

Where the first term measures the change in efficiency (EC) and the square root of the second (bracketed) term represents the change in technology (TC) between the two periods.

To calculate the distance functions necessary for calculation of the Malmquist productivity index in equation 5 , we use the linear programming techniques employed by Fare, Grosskopf , Lindgren, and Roos (1992). To calculate the Malmquist index it is necessary to calculate yearly and mixed period distance functions for all firms and years. See Grosskopf (1993, pp.179-183) for an excellent discussion of how this methodology is used to calculate the Malmquist productivity index.

An advantage of the Malmquist methodology is that it does not require information on input prices, only quantities. This eliminates possible bias associated with imprecise measurement of factor prices, especially the price of capital. Another benefit is the ease with which multiple outputs can be considered. Given the known heterogeneity of trucking output, ton-miles alone are not an adequate measure of output. This methodology allows multiple outputs. Finally, this non-parametric technique does not impose any behavioral assumptions nor does it specify any particular functional form.

\section{TOBIT REGRESSION MODEL AND DATA}

While all trucking firms use trucks and trailers, the service they provide is quite different depending on whether the firm provides general freight or specialized commodity carriage. For the purposes of this study, we concentrate on general freight commodity carriers. All of the data on information technology use and marketing strategy were obtained from the MCSOT survey as de-scribed in USDOT (1999). The MCSOT survey instrument was sent to 1,800 motor carrier firms of which 760 returned useable surveys. Although there were a total of 347 general freight firms that responded to the MCSOT survey, only 124 of those firms had complete data sets as required for this analysis. The MCSOT data were collected only for two years, 1996 and 1998.

To calculate the Malmquist Index and its components requires data from two periods. The data used for the Malmquist was obtained from the authors of the MCSOT (USDOT, 1999) survey. As explained in Chakrabortny and Kazarosian (2001), the financial and operating statistics were collected by the U.S. Department of Transportation and disseminated in the American Trucking Association's Motor Carrier Annual Report and Transportation Technical Services' Blue Book of the Trucking Industry. Form $\mathrm{M}$, the survey trucking firms used to report the financial and operating statistics data, changed in 1998 and data were not defined in the same way as previous years. The latest year for which data required for the Malmquist were reported in a consistent manner, was 1997 . We are exploring the relationship between information technology and productivity and the MCSOT technology data were available only for 1996 and 1998. Thus, to compare the productivity measure and the technology measures, we had to focus on the 1996 MCSOT technology data. We use 1995 and 1997 as the years over which to calculate the Malmquist productivity and component indices since those years surround the 1996 MCSOT data point. This will let us capture productivity gains for firms that did not use these technologies in 1995, adopted them in 1996, and subsequently experienced pro- 
ductivity gains. Ideally, we would have data on the year in which the technology was adopted, but this information is not available.

The following variables were used as inputs in the calculation of the Malmquist Productivity Index: number of employees, number of power units, and gallons of fuel (calculated by taking vehicle miles and dividing by five). On the output side we used ton-miles, average length of haul, and average load as attributes of the output. See Table 2 for summary statistics on the variables used in calculation of the productivity indices.

Note that the Malmquist Index (MALM) is the product of EC and TC so that it is possible that a carrier could have an efficiency change greater than one $(\mathrm{EC}>1)$ ) (which indicates that the firm is moving closer to its efficient production frontier) at the same time that the technical change experiences a change less than one ( $\mathrm{TC}<1$ ), with the result that the overall Malmquist (MALM) might be equal to 1 (indicating no productivity change). Just looking at the overall MALM Index would miss the improvement that is taking place in economic efficiency indicated by the EC component index. It is for this reason that we look at the component indices as well as the overall Malmquist.
Once the productivity indices are obtained, the next step is to see if we can identify factors which contribute to productivity. We use a tobit regression model where the dependent variables are alternatively the Malmquist (MALM) and its component indices of economic change (EC) and technical change (TC). These dependent variables are then regressed on independent variables expected to affect productivity.

The tobit regression is thus specified as 6a-c:

(6a) MALM $=a_{0}+a_{1}$ SATCOM $+a_{2}$ $\mathrm{EDI}+a_{3} \mathrm{LFR}+a_{4}$ GROSSREV $+a 5$ OOP $+a_{6}$ UNION

(6b) $\mathrm{EC}=a_{0}+a_{1}$ SATCOM $+a_{2}$ EDI $+a_{3} \mathrm{LFR}+a_{4}$ GROSSREV $+a 5$ $\mathrm{OOP}+a_{6}$ UNION

(6c) $\mathrm{TC}=a_{0}+a_{1} \mathrm{SATCOM}+a_{2} \mathrm{EDI}+$ $a_{3} \mathrm{LFR}+a_{4}$ GROSSREV $+a 5$ $\mathrm{OOP}+a_{6} \mathrm{UNION}$

While we would have preferred to include each of the individual information technologies as a separate independent dummy variable, the small number of firms with complete data sets (124) and the fact that many firms employed more than one of these technologies, resulted in near singular matrices. To deal with this statistical problem,

Table 2: Summary Statistics for Data Used in the Estimation of the Malmquist Index

\begin{tabular}{lrrrr}
\hline & \multicolumn{2}{c}{1995} & \multicolumn{2}{c}{1997} \\
\cline { 2 - 5 } & \multicolumn{1}{c}{ Mean } & Std Deviation & Mean & Std Deviation \\
\cline { 2 - 5 } Inputs & & & & \\
Number of Employees & 1,235 & 3,938 & 1,330 & 4,109 \\
Number of Power Units & 548 & 1,540 & 564 & 1,454 \\
Gallons of Fuel & 7,371 & 19,655 & 8,235 & 20,116 \\
Outputs & & & & \\
Ton-miles & 501,177 & $1,468,224$ & 650,760 & $2,092,355$ \\
Average Length of Haul (000 miles) & 564 & 488 & 575 & 480 \\
Average Load (tons) & 13 & 6 & 13 & 6 \\
\hline Source: Fing
\end{tabular}

Source: Financial and operating statistics data from ATA and TTS statistics provided by the authors of the U.S. DOT (1999) MCSOT study. 
we selected two technologies, SATCOM and EDI, to represent high tech on-board technologies and backroom technologies, respectively.

Table 2 summaries technology use for the 347 general freight commodity carriers in the MCSOT data as well as for the 124 of these firms which had complete data sets available for use in this study. Of the 124 firms in the 1996 sample, 52 firms used EDI, making it the most popular backroom technology. Of these 52 firms using EDI, 35 also used CAD and 21 used CAR. Only 45 firms used CAD, so most of the CAD users also had EDI. Similarly, there were 33 firms using CAR of which 21 used both CAR and EDI. Given the higher incidence of EDI use in the sample and the fact that EDI was the backroom technology that showed the largest increase in usage for general freight motor carriers between 1996 and 1998, the decision was made to specify the tobit model using EDI as the independent variable representing backroom technology.

Similarly, instead of using all the onboard technologies (AVL, OBC, and SAT-
COM) we selected SATCOM to represent the group of on-board information technologies. OBC was used by a very small number of general freight firms (only 6\% of total general freight carriers used OBC as shown in Table 3). SATCOM was used most often by firms in the 1996 sample with 32 of the 124 firms having a SATCOM system. Only 24 firms had AVL and of these, 22 also had SATCOM. SATCOM was also the on-board technology with the largest increase in usage by general freight firms during the 1996-1998 sample time period .

Standard economic theory suggests that adoption of new technologies leads to productivity increases. This is consistent with microeconomic theory that suggests the firms that survive in the long run are those that adopt productivity-enhancing technologies which give them a competitive advantage. Accordingly, we use the 1996 MCSOT technology data in this study because we do not have 1998 data for calculating the Malmquist.

The other independent variables included in this tobit regression include the firm's marketing strategy (LFR), gross firm

Table 3: Number of MCSOT Survey General Freight Firms

Using Information Technologies in 1996 and 1998

(Percent of respective sample in parentheses)

\begin{tabular}{|c|c|c|c|c|}
\hline & \multicolumn{2}{|c|}{$\begin{array}{l}\text { All General Freight } \\
\qquad(n=347)\end{array}$} & \multicolumn{2}{|c|}{$\begin{array}{c}\text { Subsample with Complete } \\
\text { Data }(n=124)\end{array}$} \\
\hline & 1996 & 1998 & 1996 & 1998 \\
\hline SATCOM & 74 (21\%) & 117 (34\%) & 32 (26\%) & 49 (40\%) \\
\hline OBC & $20(6 \%)$ & $28(8 \%)$ & $9(7 \%)$ & 13 (11\%) \\
\hline AVL & 49 (14\%) & 85 (24\%) & 24 (19\%) & 39 (32\%) \\
\hline EDI & 122 (35\%) & 176 (51\%) & 52 (42\%) & 76 (61\%) \\
\hline CAR & 77 (22\%) & 117 (34\%) & 33 (27\%) & 46 (37\%) \\
\hline CAD & 114 (33\%) & 158 (46\%) & 45 (46\%) & 67 (54\%) \\
\hline
\end{tabular}

Source: Unpublished data collected in the MCSOT (USDOT,1999) survey and provided to the author. 
revenue (GROSSREV), percent of owner operators (OOP), and percent unionized (UNION).

The marketing strategy dummy, LFR, was defined as being equal to one if LFR was ranked either as the number one or two marketing strategy. LFR was specified in this way because there is considerable evidence that shippers want both competitive rates (LFR) and on-time performance (OTP). This way cost-conscious firms which ranked OTP as their number one strategy and LFR as number two, did not get excluded. It was expected that firms which ranked LFR high (as number one or two strategy) would be more cost conscious and exhibit higher productivity than those which ranked LFR as third, fourth or fifth in importance. This means that we expect the estimate of $a_{3}$ to be positive.

We include a measure of firm size, gross revenues (GROSSREV) to control for firm size. Given the observed increases in concentration in the motor carrier industry in recent years, it has often been argued that larger firms are simply taking advantage of efficiencies related to larger network systems. If this is valid, such increases in efficiency should translate into higher productivity and we would expect a positive estimated coefficient for $a_{4}$.

The impact of owner-operators on productivity is uncertain. Hubbard (2001) argues that firms use owner-operators more in situations where they do not have on-board monitoring in place. His assumption is that owner-operators have a greater vested interest in providing efficient service than drivers who do not own their vehicles and do not earn residual rents from the services provided. The finding that owner-operator usage declines with the adoption of on-board monitoring technologies suggests that the on-board computers may have more impact on the organization of the firms (company versus leased services) than productivity. On the other hand, there is considerable anecdotal evidence (Wyckoff and Maister, 1975) that owner-operators are less reliable and harder to coordinate than company drivers. The latter view would suggest that the use of owneroperators might be negatively related to productivity. Thus, it is difficult to predict the expected sign of the $a_{5}$ variable.

Finally, unionization is a factor that often has been hypothesized to have an impact on productivity. Kerkvliet and McMullen (1997) find that unionized firms have a higher cost structure, but their study does not deal with productivity. If unionized workers are less productive (because of work rules, etc. that result in lower productivity), we would expect to see a higher cost structure. However, if union workers are more productive, then they would also be paid more, also increasing costs. Thus, we include a variable, UNION, to indicate the extent to which the trucking firm's labor force is unionized. If $\mathrm{a}_{6}$ is positive, then unionized firms are more productive; a negative estimated $\mathrm{a}_{6}$ would indicate that unionization decreases productivity.

Table 4: Means and Standard Deviation for 1996 Tobit Regression Variables (n=124)

\begin{tabular}{lcc}
\hline & Mean & Standard Deviation \\
\cline { 2 - 3 } Gross Rev (\$00) & $\$ 105,794.80$ & $\$ 332,185.82$ \\
Union (\%) & 14 & 26 \\
OOP (\%) & 22 & 30 \\
\hline
\end{tabular}

See text for variable definitions. 
We follow Kerkvliet and McMullen (1997) and use the percent of total pension contributions which are classified as "health and welfare" contributions as a proxy for firm unionization. Discussions with industry experts indicated that "health and welfare" contributions are almost exclusively those paid into pension plans administered by unions, thus serving as a good proxy for the amount of union activity within a firm.

See Table 4 for summary statistics on the dependent variables used in the tobit regressions.

It should be noted that there are many other variables that could theoretically be included in this analysis. However, a combination of a small sample size, many discrete $(0,1)$ variables, and the availability of accurate data resulted in our limiting our study to the above variables. For instance, it has been suggested that firms which operate in different geographic regions may have different productivity. However, given the data set it was also impossible to identify geographic regions where the firms operated - the only information available was where the firm headquarters was located.

Another possibility would be to distinguish between less-than-truckload (LTL) and truckload (TL) firms since LTL firms make extensive use of terminal and handling facilities. However, in the calculation of the Malmquist Index, average load was used as an output variable. Since LTL firms typically have smaller average loads, this is already accounted for in the productivity measure. To double check, an LTL dummy was included in a preliminary run of the tobit regression and it was never statistically significant. Given the large number of discrete dummy variable already used here, the decision was made not to include LTL in the final model specification.

\section{RESULTS}

The Malmquist Index results are pre-sented in Table 5 for the 124 firms for which all required data were available. The first column lists the overall Malmquist Index (MALM), the second column is the economic efficiency change (EC), and the third column is the technological efficiency change (TC). In this table a number greater than one indicates that there has been productivity or efficiency growth; a number less than one indicates decreases in productivity or efficiency; a number equal to one indicates no change.

While EC $>1$ has a clear cut economic interpretation - it means that the firm is moving closer to its efficient production frontier and thus becoming more economically efficient, it is more difficult to interpret the technological change index TC. A TC $>1$ could mean that the firm has increased efficiency because it has adopted a more efficient technology, such as the information technologies considered here. However, a change in TC could also mean that the firm has changed its marketing strategy from one based more on service quality to a lowest freight rate (LFR) strategy.

A Malmquist Index (MALM) > 1 may result from either a firm using existing resources more efficiently (EC $>1)$, from adopting a new marketing strategy or technology (TC $>1$ ), or some combination of the two. For instance, J.B. Hunt shows a Malmquist Index of 2.06 which indicates high productivity growth. Almost all of this is caused by an EC $=2.04$ which suggests that the firm is using existing resources in a more efficient manner rather than doing anything which affects TC. Buanno Transportation shows a Malmquist of 1.26 which results primarily from an increase in technological efficiency change (TC) of 1.32 while there is a slight regression in economic efficiency change $(E C=.96)$. Finally, a firm such as H\&W Trucking shows practically no overall productivity change as indicated by a Malmquist of .99, but this is caused by a large positive technological efficiency change $(\mathrm{TC}=1.39)$ at the same time that there was a decrease in economic efficiency (EC $=.72$ ).

Results from tobit regressions 6 (a-c) are presented in Table 6 . Although none of these variables have a significant impact on the overall Malmquist (MALM), some have significant impacts on its economic efficiency (EC) or technical efficiency (TC) components. 
The Impact of Information Technology on Motor Carrier Productivity

Table 5: Malmquist Index and Component Efficiency and Technological Change Index

\begin{tabular}{|c|c|c|c|}
\hline Company & $\begin{array}{c}\text { Malmquist } \\
\text { Index }\end{array}$ & $\begin{array}{c}\text { Efficiency } \\
\text { Change }\end{array}$ & $\begin{array}{c}\text { Technical } \\
\text { Change }\end{array}$ \\
\hline Wilhelm Trucking Co. & 1.47 & 1.49 & 0.98 \\
\hline Alvan Motor Freight, Inc. & 0.84 & 0.67 & 1.25 \\
\hline Midwest Motor Express, Inc. & 0.98 & 0.88 & 1.11 \\
\hline Roadway Express, Inc. & 1.12 & 1.00 & 1.12 \\
\hline National Freight, Inc. & 0.96 & 0.94 & 1.03 \\
\hline Hatcher Trucking Co., Inc. & 1.06 & 0.70 & 1.51 \\
\hline Blue \& Gray Transportation & 0.88 & 0.84 & 1.04 \\
\hline Los Angeles-Yuma Freight & 1.05 & 0.95 & 1.11 \\
\hline MCO Transport, Inc. & 0.96 & 0.95 & 1.00 \\
\hline Volpe Express, Inc. & 0.97 & 0.85 & 1.14 \\
\hline Devine Intermodal & 1.01 & 0.95 & 1.06 \\
\hline ABF Freight System, Inc. & 1.09 & 1.01 & 1.09 \\
\hline T. P. Freight Lines, Inc. & 0.84 & 1.00 & 0.84 \\
\hline Youngblood Truck Lines & 1.00 & 1.00 & 1.01 \\
\hline Consolidated Freightways & 1.11 & 1.00 & 1.11 \\
\hline Buske Lines, Inc. & 0.67 & 0.66 & 1.02 \\
\hline Dick Harris \& Son Trucking & 0.99 & 0.95 & 1.04 \\
\hline Graham Ship By Truck Co. & 1.22 & 1.23 & 0.99 \\
\hline A.A.A Cooper Transportation & 1.01 & 0.89 & 1.13 \\
\hline Waller Truck Co., Inc. & 0.55 & 0.55 & 0.98 \\
\hline Bryan Truck Line, Inc. & 0.45 & 0.43 & 1.04 \\
\hline Wilson Trucking Corp & 1.06 & 0.75 & 1.41 \\
\hline Houff Transfer, Inc. & 1.06 & 1.03 & 1.02 \\
\hline New Penn Motor Express, Inc. & 1.03 & 0.86 & 1.21 \\
\hline Brown Line, Inc. & 0.85 & 0.81 & 1.05 \\
\hline Hunt Transportation, Inc. & 0.9 & 0.89 & 1.02 \\
\hline Paul Musslewhite Trucking & 0.99 & 0.66 & 1.49 \\
\hline Seward Motor Freight, Inc. & 1.12 & 1.12 & 1.01 \\
\hline Watkins Motor Lines, Inc. & 1.02 & 1.00 & 1.01 \\
\hline Estes Express Lines & 1.23 & 1.01 & 1.21 \\
\hline Severance Trucking Co., Inc. & 0.95 & 0.63 & 1.51 \\
\hline Brown Transfer Co. & 0.58 & 0.49 & 1.20 \\
\hline B \& D Transfer, Inc. & 1.00 & 0.88 & 1.13 \\
\hline Old Dominion Freight Line & 1.11 & 1.01 & 1.10 \\
\hline A. J. Metler Hauling \& Rig & 1.37 & 1.40 & 0.98 \\
\hline Baylor Trucking, Inc. & 1.00 & 0.99 & 1.01 \\
\hline Overnite Transportation Co. & 1.01 & 0.91 & 1.11 \\
\hline Southeastern Freight Lines & 0.77 & 0.69 & 1.12 \\
\hline Buanno Transportation & 1.26 & 0.96 & 1.32 \\
\hline W. C. McQuaide, Inc. & 2.81 & 2.56 & 1.10 \\
\hline Eck Miller Transportation & 1.33 & 1.33 & 1.00 \\
\hline James H. Clark \& Son & 1.00 & 1.00 & 1.00 \\
\hline John Cheeseman Trucking & 0.19 & 0.19 & 1.01 \\
\hline Craig Transportation Co. & 0.88 & 0.89 & 0.99 \\
\hline
\end{tabular}


Table 5: continued

\begin{tabular}{|c|c|c|c|}
\hline Company & $\begin{array}{l}\text { Malmquist } \\
\text { Index }\end{array}$ & $\begin{array}{c}\text { Efficiency } \\
\text { Change }\end{array}$ & $\begin{array}{c}\text { Technical } \\
\text { Change }\end{array}$ \\
\hline A \& B Freight Line, Inc. & 0.96 & 0.89 & 1.08 \\
\hline Cape Cod Express, Inc. & 0.86 & 0.63 & 1.36 \\
\hline Averitt Express, Inc. & 0.96 & 0.93 & 1.04 \\
\hline Milan Express Co., Inc. & 0.93 & 0.90 & 1.02 \\
\hline American Freightways, Inc. & 0.94 & 0.82 & 1.15 \\
\hline Southwest Truck Service & 1.23 & 1.00 & 1.23 \\
\hline Cresco Lines, Inc. & 1.06 & 0.99 & 1.07 \\
\hline Professional Transportation Services & 0.85 & 0.49 & 1.72 \\
\hline B-D-R Transport, Inc. & 1.11 & 1.12 & 0.99 \\
\hline East Penn Trucking, Inc. & 0.99 & 0.94 & 1.05 \\
\hline J. B. Hunt Transport, Inc. & 2.06 & 2.04 & 1.01 \\
\hline Wallace Transport, Inc. & 1.36 & 1.32 & 1.03 \\
\hline Lisa Motor Lines, Inc. & 0.87 & 0.93 & 0.93 \\
\hline Eidson \& Ussery, Inc. & 0.97 & 0.88 & 1.10 \\
\hline Art Pape Transfer, Inc. & 1.00 & 1.02 & 0.98 \\
\hline Adams Transit, Inc. & 1.02 & 0.95 & 1.07 \\
\hline Tennessee Express, Inc. & 1.03 & 1.00 & 1.03 \\
\hline Cannon Express Corp. & 1.47 & 1.48 & 0.99 \\
\hline Danny Herman Trucking & 0.81 & 1.00 & 0.81 \\
\hline H \& W Trucking Co., Inc. & 0.99 & 0.72 & 1.39 \\
\hline Central Virginia Trucking & 1.05 & 1.04 & 1.01 \\
\hline American Pacific Forwarders & 1.10 & 1.00 & 1.10 \\
\hline Perfetti Trucking, Inc. & 1.25 & 1.26 & 0.99 \\
\hline Penske Logistics, Inc. & 0.97 & 0.95 & 1.03 \\
\hline East-West Motor Freight, Inc. & 1.00 & 0.98 & 1.02 \\
\hline Scalea’s Airport Service & 0.69 & 0.45 & 1.53 \\
\hline Black Hills Trucking, Inc. & 1.01 & 0.83 & 1.21 \\
\hline Ronwal Transportation, Inc. & 0.77 & 0.76 & 1.02 \\
\hline Truck Service, Inc. & 0.99 & 1.01 & 0.98 \\
\hline Atlantic Carriers, Inc. & 1.01 & 1.01 & 1.00 \\
\hline Adrian Carriers, Inc. & 0.99 & 0.97 & 1.02 \\
\hline A. N. Webber, Inc. & 1.17 & 1.17 & 1.00 \\
\hline Nationwide Magazine \& Book & 0.98 & 0.94 & 1.04 \\
\hline M. C. Van Kampen Trucking & 0.97 & 0.70 & 1.39 \\
\hline Teresi Trucking, Inc. & 1.10 & 1.08 & 1.02 \\
\hline Cowen Truck Line, Inc. & 0.93 & 0.93 & 0.99 \\
\hline T. B. \& P. Express, Inc. & 0.96 & 0.95 & 1.01 \\
\hline Shane Transport & 0.96 & 0.89 & 1.08 \\
\hline Tony’s Express, Inc. & 2.29 & 2.19 & 1.05 \\
\hline Maverick Transportation & 1.00 & 0.99 & 1.01 \\
\hline Nationwide Express, Inc. & 0.99 & 0.64 & 1.54 \\
\hline K \& K Trucking, Inc. & 1.14 & 0.98 & 1.16 \\
\hline Customized Transportation & 1.01 & 1.02 & 0.99 \\
\hline GTL Transport Co., Inc. & 0.94 & 0.91 & 1.03 \\
\hline SC Transport & 1.02 & 1.01 & 1.01 \\
\hline The Great American Trucking & 3.82 & 1.00 & 3.82 \\
\hline
\end{tabular}


Table 5: continued

\begin{tabular}{|c|c|c|c|}
\hline Company & $\begin{array}{c}\text { Malmquist } \\
\text { Index }\end{array}$ & $\begin{array}{c}\text { Efficiency } \\
\text { Change }\end{array}$ & $\begin{array}{c}\text { Technical } \\
\text { Change }\end{array}$ \\
\hline B.I. Transportation, Inc. & 1.04 & 1.02 & 1.01 \\
\hline Comtrak, Inc. & 1.01 & 0.98 & 1.03 \\
\hline Penn’s Best, Inc. & 1.18 & 1.16 & 1.02 \\
\hline Benny Whitehead, Inc. & 0.95 & 0.67 & 1.42 \\
\hline Jevic Transportation, Inc. & 1.94 & 1.87 & 1.04 \\
\hline T \& T Trucking, Inc. & 0.91 & 1.00 & 0.91 \\
\hline Tripp Brothers Trucking & 1.02 & 1.00 & 1.02 \\
\hline USA Truck, Inc. & 0.99 & 0.99 & 1.00 \\
\hline Smith Bros. Trucking, Inc. & 0.94 & 0.90 & 1.05 \\
\hline Dick Lavy Trucking, Inc. & 0.99 & 1.03 & 0.97 \\
\hline Jolliff Transportation & 1.16 & 1.13 & 1.03 \\
\hline Hansen Trucking & 1.15 & 1.10 & 1.04 \\
\hline Wausau Carriers, Inc. & 0.95 & 0.95 & 0.99 \\
\hline Emerson Transportation Division & 1.05 & 1.05 & 1.00 \\
\hline S \& S Truck Line, Inc. & 1.01 & 1.01 & 1.00 \\
\hline Dirksen Transportation, Inc. & 1.53 & 1.50 & 1.02 \\
\hline Bradford Trucking, Inc. & 0.95 & 1.00 & 0.95 \\
\hline Dist-Trans Co. & 0.70 & 0.80 & 0.88 \\
\hline Celebrity Freight Systems & 1.00 & 1.02 & 0.98 \\
\hline Barr-Nunn Transportation & 0.92 & 0.91 & 1.00 \\
\hline T.T.I., Inc. & 1.05 & 1.00 & 1.05 \\
\hline Transport Distribution Co. & 0.99 & 0.97 & 1.02 \\
\hline Hot Shot Express, Inc. & 0.96 & 0.77 & 1.25 \\
\hline Pope Transport Co. & 0.99 & 0.97 & 1.02 \\
\hline Best Way Express, Inc. & 1.22 & 0.93 & 1.32 \\
\hline Quick Delivery Service, Inc. & 1.39 & 1.19 & 1.16 \\
\hline S \& S Transportation, Inc. & 1.01 & 0.97 & 1.04 \\
\hline Stever Trucking, Inc. & 0.87 & 0.86 & 1.02 \\
\hline Pilot Transport, Inc. & 0.84 & 0.54 & 1.54 \\
\hline Atkinson Freight Lines of PA & 1.01 & 1.00 & 1.01 \\
\hline Jack Jones Trucking, Inc. & 0.87 & 0.68 & 1.28 \\
\hline Adams Motor Express, Inc. & 0.99 & 0.97 & 1.01 \\
\hline Inter-Cal Contract Carriers & 1.15 & 0.81 & 1.42 \\
\hline Americana, Inc. & 0.97 & 0.93 & 1.04 \\
\hline
\end{tabular}


Table 6: Tobit Regression of MALM, TC, EC on EDI, SATCOM, LFR, UNION, OOP and GGREV

\begin{tabular}{lrrr}
\hline Variable & MALM & EC & \multicolumn{1}{c}{ TC } \\
\hline C & .977 & .90 & 1.10 \\
EDI & $(16.46)$ & $(20.26)$ & $(25.15)$ \\
& .09 & .15 & -.08 \\
SATCOM & $(1.25)$ & $(2.71)$ & $(-1.43)$ \\
& -.11 & -.06 & -.05 \\
LFR & $(-1.29)$ & $(-.94)$ & $(-.78)$ \\
& .08 & -.04 & .14 \\
UNION & $(1.06)$ & $(-.71)$ & $(2.52)$ \\
& .20 & .24 & -.09 \\
OOP & $(1.46)$ & $(2.29)$ & $(-.82)$ \\
& .12 & -.02 & .12 \\
GRREV & $(1.04)$ & $(-.19)$ & $(1.34)$ \\
& $.55 \mathrm{E}-07$ & $.19 \mathrm{E}-07$ & $.31 \mathrm{E}-07$ \\
& $(.49)$ & $(.29)$ & $(.37)$ \\
\hline
\end{tabular}

t-statistics in parentheses.

For instance, LFR imparts a positive and significant impact on technical efficiency (TC), confirming the hypothesis that marketing strategy has an impact on the technical efficiency component of productivity. The finding that marketing strategy affects the TC measure helps explain McMullen and Okuyama's (2000) finding that during the transition to deregulation in the 1980's, motor carrier firms, on average, experienced declines in the TC component of the Malmquist. This was observed at the same time that the firms had consistently positive efficiency (EC) gains. The positive EC gains were expected and could be attributed to firms operating more efficiently without regulations that had restricted them from operating at the lowest possible cost. McMullen and Okuyama (2000) speculated that apparent regression in technology could be explained by firms increasingly adopting higher-cost marketing strategies such as on-time performance (OTP). The results here show a clear technical efficiency advantage to firms which adopt
LFR marketing strategies, providing some collaboration for their explanation of previous results.

The use of electronic data interchange (EDI) has a positive and significant impact on economic efficiency (EC), suggesting that adoption of EDI enables a firm to use its existing resources in a more efficient manner. Thus, large increases in EDI use in the 1990's may be explained not only by firms striving to satisfy consumers as found by Crum, Johnson, and Allen (1998) but also because carriers adopting EDI were able to reap costsaving efficiency gains.

In no case does the use of owneroperators appear to be positively or negatively related to productivity or efficiency gains. While the Hubbard argument that owner-operators have a greater interest in efficient operations might suggest that those carriers using owner-operators would be expected to be more efficient, his argument also suggests that companies have adopted 
information technologies to erase these efficiency differences as companies are able to better monitor their own drivers. Accordingly, this result is not inconsistent with Hubbard's argument.

Another interesting finding is that economic efficiency of trucking firms increases as carriers are unionized as indicated by the positive and significant coefficient on the UNION variable. Previous research on the impact of unionization on truck costs has shown that unionized carriers have higher cost structures (Kerkvliet and McMullen, 1997) so this is an unexpected result. It may be due to the fact that the Malmquist and component indices are calculated using physical units rather than cost data. Thus, unionized firms may use inputs more efficiently, but this may not translate into lower costs if unionized firms have to pay higher prices for factors (such as labor). Indeed, Kerkvliet and McMullen find that unionized firms face higher factor prices not only for labor but also for fuel. Finally, there is a thread of labor literature that argues that unionized workers have better skill levels and are more content than non-unionized workers, leading to increased productivity.

Firm size and SATCOM do not appear to have a significant impact on any of the productivity or efficiency measures.

\section{CONCLUSIONS}

This paper uses a unique data set to examine the impact of marketing strategy and information technologies on productivity and efficiency for U.S. general commodity motor carriers. Although marketing strategy does not appear to have a significant impact on the overall Malmquist Productivity Index for these firms, there is a positive and significant relationship found between increases in technical efficiency and the firm's choice of a "lowest freight rate" (or LFR) marketing strategy. Accordingly, a firm which focuses on OTP or other marketing strategies may appear to be less efficient than firms adopting
LFR as a marketing objective. This is consistent with McMullen and Okuyama's (2000) argument that strategies other than LFR tend to be more resource intensive, providing different services but at higher cost. It also underscores the need to account for service-quality aspects when making interfirm com-parisons regarding motor carrier productivity and costs.

The positive impact of EDI on economic efficiency provides carriers with an additional reason for the increasing popularity of EDI. This helps explain the observed large increases in EDI throughout the 1990's. In addition to contributing to consumer satisfaction, EDI adoption may actually help firms increase efficiency and thus compete in the competitive market environment.

Finally, these overall results suggest that adoption of various information technologies may not directly increase productivity as much as previously thought. Indeed, Brynjolfson and Hitt (2000) argue that infor-mation technologies have broad powers to reduce the costs of coordination and infor-mation, but also enable firms to increase service quality and other intangible aspects of products. This is in line with Hubbard's thesis that information technologies may be adopted to allow firms to organize their production in a different manner. His example being the use of monitoring afforded by on-board computers may make firms more willing to rely on company drivers rather than owneroperators. While this may not reflect a productivity gain per se, it may enable firms to operate better in a market where owneroperators may becoming harder to find (especially during the 1990s when many owner-operators left the industry and got jobs elsewhere.) Thus, the on-board monitoring technology, such as SATCOM, may give trucking firms the ability to adapt to a changing labor market rather than imparting any large increase in efficiency. It is possible that without the technologies, efficiency would have decreased due to tight truck driver labor markets in the late 1990s. 


\section{References}

Adrangi, B., G. Chow, and K. Raffiee. “The U.S. Trucking Industry: A Profit Function Approach.” Journal of Transport Economics and Policy, (1995): 233-245.

Barnes, David. “Trucking Productivity Tops ATA 1999 Agenda.” Transport Topics, January 4, 1999.

Bruning, E.R. and R.E. Olson. "The Use of Efficiency Indexes in Testing for Scale Economies in the Motor Carrier Industry.” Journal of Transport Economics and Policy 19 (2), (1982): 277-293.

Brynjolfsson, E. and L.M. Hitt. "Beyond Computation: Information Technology, Organization, Transformation and Business Performance.” Journal of Economic Perspectives 14 (4 ), (2000): 23-48.

Caves, D.W., L.R. Christensen, and W.E. Diewert."The Economic Theory of Index Numbers and the Measurement of Input, Output, and Productivity.” Econometrica 50, (1982): 1393-1414.

Chakraborty, A. and M. Kazarosian. "Marketing Strategy and the Use of Information Technology: New Evidence from the Trucking Industry.” Research in Transportation Economics: Transportation After Deregulation 6, (2001): 71-96.

Charnes, A., W.W. Cooper, and E. Rhodes. "Measuring the Efficiency of Decision Making Units.” European Journal of Operational Research 2, (1978): 429-444.

Corsi, T.M., C.M. Grimm, K.G. Smith, and R.D. Smith. “Deregulation, Strategic Change, and Firm Performance Among LTL Motor Carriers.” Transportation Journal, (1991): 4 -13.

Crum, Johnson, and Allen.”A Longitudinal Assessment of EDI Use in the U.S. Motor Carrier Industry.” Transportation Journal 38 (1), (1998): 15-29.

Fare, R., S. Grosskopf, and W-F. Lee. "Productivity in Taiwanese Manufacturing Industries.” Applied Economics 27, (1995): 259-265.

Fare, R., S. Grosskopf, M. Norris, and Z. Zhang. "Productivity Growth, Technological Progress, and Efficiency in Industrialized Countries.” American Economic Review 84, (1994): 374-380.

Fare, R., S. Grosskopf, B. Lindgren, and P. Roos. "Productivity Developments in Swedish Pharmacies 1980-989: A Non-Parametric Malmquist Approach.” The Journal of Productivity Analysis, (1992): 8197.

Farrell, M.J. “The Measurement of Productivity Efficiency.” Journal of the Royal Statistical Society, Series A, General, 120, Part 3 (1957): 253-281.

Forsund, F.R. "Productivity Growth in Norwegian Ferries.” Fried, H.O., C.A.K. Lovell, and S. Schmidt, eds. The Measurement of Productive Efficiency: Techniques and Applications. New York and Oxford: Oxford University Press (1993): 353-373.

Grimm, C., T. Corsi, and J. Jarrell. “U.S. Motor Carrier Cost Structure Under Deregulation.” Logistics and Transportation Review 25 (3), (1989): 231-49.

Grosskopf, S. "Efficiency and Productivity”. Fried, H.O., C.A.K. Lovell, and S. Schmidt, eds. The Measurement of Productive Efficiency: Techniques and Applications. New York and Oxford: Oxford University Press (1993):160-194.

Hubbard, T.N.“Contractibility and Asset Ownership: On Board Computers and Governance in U.S. Trucking.” Working Paper. University of Chicago, 2001. 
Kerkvliet, J. and B.S. McMullen. “The Impact of Unionization on Motor Carrier Costs.” Economic Inquiry 35, (April 1997): 271-284.

Lovell, C.A.K. "Production Functions and Productive Efficiency.” Fried, H.O., C.A.K. Lovell, and S. Schmidt, eds. The Measurement of Productive Efficiency: Techniques and Applications. New York and Oxford: Oxford University Press (1993): 271-283.

McMullen, B. S. and Man-Keung Lee. "Cost Efficiency in the U.S. Motor Carrier Industry Before and After Deregulation: A Stochastic Frontier Approach.” Journal of Transport Economics and Policy 33 (3), (1999): 303-317.

McMullen, B.S. and K. Okuyama.”Productivity Changes in the U.S. Motor Carrier Industry Following Deregulation: A Malmquist Approach.” International Journal of Transport Economics 27, (2000): 335-354.

McMullen B.S. and L.R. Stanley. "The Impact of Deregulation on the Production Structure of the Motor Carrier Industry.” Economic Inquiry 26, (1987): 299-316.

McMullen, B.S. and H. Tanaka. "An Econometric Analysis of Differences Between Motor Carriers: Implications for Market Structure.” Quarterly Journal of Business and Economics 34(4), (1995): 1-16.

Shephard, R.W. Cost and Production Functions. Princeton University Press, Princeton 1953.

U.S. Department of Transportation, Office of Motor Carrier Safety. "Motor Carrier TechnologiesFleet Operational Impacts and Implications for Intelligent Transportation Systems/Commercial Vehicle Operations.” Report No FHA-MC-00-0005, October 1999.

Wyckoff, D.D. and D.H. Maister.The Owner-Operator, Independent Trucker, Lexington Books, Lexington, Mass., 1975.

B. Starr McMullen is a Professor of Economics at Oregon State University where she teaches transportation economics. She has published articles on a wide variety of transportation issues dealing with regulation/deregulation, pricing, costs, efficiency, productivity, and competition. Most of her recent research has focused on the motor carrier industry. A past president of TPUG (the Transportation and Public Utilities Group of the American Economic Association), she has served on numerous advisory and editorial boards and has been the editor of Research in Transportation Economics. 